\title{
Two converging paths: behavioural sciences and social marketing for better policies
}

\author{
François J. Dessart and René van Bavel \\ Joint Research Centre, European Commission, Seville, Spain
}

\begin{abstract}
Purpose - This commentary argues that social marketing and the application of behavioural sciences to policy constitute two converging paths towards better policies. It highlights points of convergence and divergence between both disciplines and the potential benefits of further embedding social marketing principles and methods within the recent trend of applying behavioural sciences to policy.
\end{abstract}

Design/methodology/approach - The commentary relies on a review of the behavioural sciences and social marketing literatures and on an analysis of institutional reports reviewing cases of behaviourally informed policies.

Findings - Behavioural sciences are increasingly informing policies to promote societal well-being. Social marketing has seldom been explicitly considered as being part of this phenomenon, although it is de facto. Both disciplines share similar end-goals, inform similar policy applications and are rooted in behavioural analysis. They diverge in their theoretical frameworks, their relative emphasis on behaviour change and the span of interventions they generate. Several benefits of embedding social marketing principles and methods within the current way of applying behavioural sciences to policy are identified.

Practical implications - Scholars applying behavioural sciences to policy are encouraged, when appropriate, to use the insights and methods from social marketing. Social marketing can engage in a dialogue with behavioural sciences to explore how to pilot the convergence of both approaches in practice.

Originality/value - The novelty of this contribution lies in providing the first comparison of the application of behavioural sciences to policy with social marketing, and in using the policy-making cycle framework to map the contributions and complementarities of both disciplines.

Keywords Social marketing, Policy, Behavioural economics, Nudge, Behavioural insights,

Behavioural sciences

Paper type Viewpoint

\section{Introduction}

\subsection{Behavioural sciences and policy}

Behavioural sciences study human behaviour in an attempt to understand the various factors that affect it (Berelson, 1995), and encompass psychology, behavioural economics, neuroscience and anthropology, among others. Although behavioural sciences have

(c) François J. Dessart and René van Bavel. Published by Emerald Publishing Limited. This article is published under the Creative Commons Attribution (CC BY 4.0) licence. Anyone may reproduce, distribute, translate and create derivative works of this article (for both commercial \& noncommercial purposes), subject to full attribution to the original publication and authors. The full terms of this licence may be seen at http://creativecommons.org/licences/by/4.0/legalcode

The views expressed in this article are those of the authors and do not necessarily reflect an official position of the European Commission. The authors would like to thank Emanuele Ciriolo, Fabiana Scapolo and two anonymous reviewers for their comments on earlier versions of this article. 
JSOCM 7,4

produced extensive empirical findings regarding human behaviour for decades, their explicit application to public policy emerged in the early 2000s (Madrian and Shea, 2001). "Behavioural insights", as they are often called, now inform policy issues as diverse as healthy eating, savings for pensions, energy conservation and tax collection (Lourenço et al., 2016b; Lunn, 2014; OECD, 2017; World Bank Group, 2015).

In parallel, governments have increasingly acknowledged that human behaviour is central to policy-making: policies often affect people's behaviour, and people's behaviour will often determine the success of such policies (Oullier, 2013; Shafir, 2013a, 2013b). Consequently, national governments in countries such as the UK (Behavioural Insights Team, 2011), The Netherlands (Kamp, 2014), the USA (Obama, 2015), and Germany (Dams et al., 2015) have set up dedicated teams with behavioural expertise.

\subsection{Beyond behavioural economics and nudges}

Behavioural economics has been, so far, the most influential behavioural science in policymaking, for a number of reasons. As a sub-discipline of economics, behavioural economics has benefited from economics' already-established position in policy-making. Economists have indeed a long tradition in providing advice to policy-makers because classical economic theory is the basis of most legal systems (Micklitz et al., 2011). Economists are also well-represented among policy-makers (Adam, 2017), making them naturally more attuned to the findings from behavioural economics than from other behavioural sciences. Finally, policy-makers' interest in behavioural sciences was triggered primarily by the publication of the book Nudge (Thaler and Sunstein, 2008), which presented a predominantly behavioural economics approach and proposed relatively simple and unexpected - and therefore attractive - solutions to policy issues (Lotenberg, 2015).

As a result of the prominence of behavioural economics, initial attempts to apply behavioural sciences to policy mainly relied on the nudge approach, which focuses on changes to the choice architecture, i.e. the way options are presented to citizens and consumers (Bogliacino et al., 2016). For instance, proposing opt-out schemes rather than optin schemes in company-run savings plans alters the way options are presented and more than doubles participation rates (Madrian and Shea, 2001). Progressively, the approach has expanded to a broader palette of behavioural sciences beyond behavioural economics and nudges (Lunn, 2014). The use of social norms feedback to promote prosocial behaviours such as energy conservation, for instance, is primarily based on the social psychology literature (Cialdini and Goldstein, 2004). The methodological toolbox of behavioural sciences applied to policy has also expanded, going beyond lab experiments and randomised controlled trials to incorporate qualitative methods such as focus groups and ethnography (van Bavel et al., 2013).

\subsection{The positioning of social marketing}

Social marketing "seeks to develop and integrate marketing concepts with other approaches to influence behaviours that benefit individuals and communities for the greater social good" (International Social Marketing Association, European Social Marketing Association, and Australian Association of Social Marketing, 2013). Since much earlier than behavioural sciences, its principles and methods have been applied to inform policies promoting healthy, safe and environmentally friendly lifestyles.

Because social marketing leverages behavioural insights to promote behavioural change (French and Russell-Bennett, 2015), it is de facto part of the growing trend of applying behavioural sciences to policy. This fact has not been sufficiently acknowledged. Out of hundreds of cases of behaviourally informed policies reviewed by international 
organisations (Lourenço et al., 2016a; OECD, 2017; World Bank Group, 2015), as little as two instances explicitly mention social marketing concepts and tools. The pioneering UK Behavioural Insights Team's three biannual update reports (Behavioural Insights Team, 2011, 2015, 2016), which also showcase hundreds of applications of behavioural sciences to policy, only include one explicit mention of social marketing. Likewise, recent international conferences (e.g. Behavioral Exchange, Annual Conference of the Behavioral Science and Policy Association), the comprehensive edited volume by Shafir (2013b) and new journals dedicated to this discipline (e.g. Behavioral Science \& Policy and Behavioural Public Policy) have not included contributions using an explicit social marketing approach.

In summary, the application of behavioural sciences to policy has not yet fully embraced - at least explicitly - the methods and findings of social marketing. This is a missed opportunity, as both disciplines are very much complementary. In the following sections, we first outline points of convergence and divergence, and then examine how this complementarity can be capitalised upon at the different steps of policy-making.

\section{Points of convergence and points of divergence}

\subsection{Points of convergence}

To a large extent, social marketing and behavioural sciences applied to policy overlap. Five clusters of convergence can be identified between both disciplines.

2.1.1 End-goals and policy applications. Social marketing's overarching objective is to contribute to greater social good (International Social Marketing Association, European Social Marketing Association, and Australian Association of Social Marketing, 2013), similar to the focus of behavioural sciences applied to policy on human welfare (Shafir, 2013a). Towards that end-goal, both disciplines inform a broad and similar canvas of policy areas such as health, environment, energy and transport. Despite this overlap, there are some specific policy areas that have been tackled relatively more by one or the other discipline, such as financial decision-making (e.g. pension savings, tax collection) in the case of behavioural sciences (Chetty et al., 2014; Madrian, 2014).

2.1.2 Citizen centralism and behavioural analysis. Social marketing and behavioural sciences applied to policy share the commonality of being citizen-centric (French and Russell-Bennett, 2015). Against a backdrop of top-down policy-making where individual preferences and behaviours are assumed, both social marketing and behavioural sciences take the citizen as the starting point for building policy interventions. The analysis of the causes of human behaviour is therefore a central feature of both social marketing and behavioural sciences applied to policy (Aspara and Tikkanen, 2017; Shafir, 2013a).

2.1.3 Multidisciplinary approaches. Because of the nature of its focus, social marketing is expected to be a multidisciplinary field of study (French, 2011). Social marketers are not confined to the theoretical foundations and methods of any particular discipline, drawing on diverse fields such as economics, psychology, sociology and communications theory (Peattie and Peattie, 2003). A similar, yet less developed, multidisciplinary approach exists in the field of behavioural sciences for policy-making, which has primarily applied insights from behavioural economics and social psychology (Shafir, 2013a).

2.1.4 Citizens' sovereignty. Another point of convergence between both approaches is the tenet that citizens and consumers need to be persuaded, not coerced (Russell-Bennett, 2016). Indeed, encouraging behaviours that benefit the majority of society while allowing freedom of choice has been identified as a cornerstone of social marketing (Gordon et al., 2016). Likewise, part of the rise in popularity of the application of behavioural sciences to policy is owing to nudges' emphasis on libertarian paternalism, i.e. guiding behaviour while still giving citizens freedom to choose (Thaler and Sunstein, 2008). 
JSOCM 7,4
2.1.5 Pretesting and impact evaluation. The rigorous pretesting of different behaviourally informed policy options, usually through lab experiments or small-scale randomised controlled trials, is at the heart of the application of behavioural sciences to policy (Oullier, 2013). The evaluation of the actual impact of policies informed by behavioural sciences is encouraged, but is too often lacking. The same principles of ex ante and ex post evaluation and reporting of policy impacts are applied in social marketing (International Social Marketing Association, European Social Marketing Association, and Australian Association of Social Marketing, 2013).

\subsection{Points of divergence}

Despite clear points of convergence at a general level, both disciplines differ on some more specific attributes.

2.2.1 Theoretical foundations. Although social marketing is not confined to using marketing principles, its core concepts mirror those of marketing (French and RussellBennett, 2015). The marketing mind-set adopted by social marketing entails the creation of value through the provision of social offerings (e.g. ideas, understanding, experiences and environments) via a process of exchange. Social marketing leverages concepts such as the (social) marketing mix, segmentation, targeting and competition. In contrast, the starting point for the application of behavioural sciences to policy was, for the most part, behavioural economics. The recognition that humans do not behave as neoclassical economics assumes is perhaps the single most important premise in the application of behavioural sciences to policy. Many contributions of behavioural sciences to policy therefore leverage concepts from behavioural economics such as loss aversion, time inconsistency and status quo bias.

2.2.2 Behavioural change. Social marketing's goal is primarily to influence behaviour (International Social Marketing Association, European Social Marketing Association, and Australian Association of Social Marketing, 2013), although recent research highlights the limitations of this focus (Tapp and Spotswood, 2013). Likewise, the application of behavioural sciences to policy often seeks to promote certain behaviours (Shafir, 2013a). But behavioural change is not always the objective. It may be that behavioural sciences will help provide citizens and consumers with the right information by designing and testing ways to make it is easy to understand, without necessarily steering them in a certain direction. For instance, in 2010 the European Commission ran a behavioural study to inform the design of information disclosure requirements for financial products (Chater et al., 2010). When it then issued a regulation partially based on this study (European Union, 2014), it did not seek to encourage consumers to choose specific financial products, rather just to help them make better-informed decisions.

2.2.3 Span of interventions. Social marketing involves rolling out fully integrated social programmes using the 7Ps marketing mix (social product, social price, social place, social promotion, people, processes and physical evidence; Russell-Bennett et al., 2013), or other, more novel integrated approaches such as COM-SM (Tapp and Spotswood, 2013). Social marketing often intends to address the multiple causes of behaviour by first developing a holistic and integrated understanding of the relevant psychological, economic and also cultural factors (Gordon et al., 2016; Tapp and Spotswood, 2013). The wide span of social marketing is also reflected in its focus not only on individual level change, but also societal changes by intending to challenge the macro institutional norms that shape individual behaviours (Kennedy, 2015). In contrast, policies informed by behavioural sciences, especially those relying on nudging approaches, have tended to be more specific, entailing small changes in citizens' choice architecture (Sunstein, 2014) rather than fully integrated programmes. 
2.2.4 Citizens' level of involvement. Social marketing programmes actively involve citizens in designing and implementing interventions through a process of co-creation (Clarke et al., 2007) so that they are actors of their own behavioural change. Behavioural sciences, as they are currently applied to policy, do sometimes involve citizens in qualitative interviews or focus groups to get an in-depth understanding of their behaviour in relation to the policy issue (van Bavel et al., 2013). However, there is not much evidence of citizens being involved in the actual design of a policy remedy informed by behavioural sciences.

\section{Converging both disciplines to inform policy-making}

There are clear convergences between social marketing and behavioural sciences applied to policy and their differences may complement each other. It is therefore worth exploring how the application of behavioural sciences to policy-making can more explicitly leverage social marketing to improve societal well-being. In the next paragraphs, we describe how behavioural sciences inform the different stages of the policy-making process, based in part on the European Commission's (2015) "Better Regulation Toolbox", and how this discipline could benefit from social marketing's insights and approaches to overcome some of its weaknesses. The benefits of this proposed convergence are clear for some phases of the policy-making cycle; for others, we call for a debate.

The policy process can be broken down into five steps (adapted from Jann and Wegrich, 2007):

(1) problem definition (i.e. understanding of the magnitude and causes of the issue);

(2) formulation (i.e. design of solutions to address the issue and assessment of their expected impact);

(3) decision-making (i.e. adoption of a policy solution by policy-makers);

(4) implementation (i.e. practical application of the policy solution); and

(5) evaluation (i.e. assessment of the actual impact of the policy solution on the issue and feedback loop to inform new policies).

\subsection{Problem definition}

By identifying the possible underlying psychological drivers of a policy issue, besides drivers linked to market failures and regulation failures, behavioural sciences are well placed to contribute to the problem definition phase of the policy-making cycle. Unfortunately, behavioural sciences are often involved too late in the policy-making cycle, at the stage of implementing solutions. The nudge approach, in particular, has been criticised for focusing too much on policy solutions without having a thorough understanding of the psychological drivers of policy issues (Marchiori et al., 2017). There are, however, a growing number of cases of explicit use of behavioural sciences in the problem definition phase of policy issues. For instance, the European Commission contracted a literature review of the psychological drivers causing excessive online-gambling (e.g. over-confidence, sunk cost fallacy) before testing different policy options to tackle the issue (Codagnone et al., 2014) and issuing a recommendation based on the findings (European Commission, 2014).

The application of behavioural sciences to policy would certainly benefit from embedding social marketing approaches in the problem definition phase. Social marketing may bring a more holistic understanding of the policy issue and of its causes by identifying the competition aspects in the behavioural analysis (Schuster, 2015), by understanding the marketing practices of the supply side (Hastings and Saren, 2003), and by investigating macro-systemic causes of behaviours besides individual drivers (Kennedy, 2015). For 
JSOCM 7,4

instance, in the above-mentioned case of excessive online-gambling, social marketing could lead to better regulation by providing a better understanding of marketing practices designed to hook gamblers and make them addictive. Similarly, social marketing can complement a behaviourally informed examination of people's reluctance to pay their taxes on time (Hallsworth et al., 2017) by taking the tax system in its entirety as a contextual factor guiding individual behaviour and highlighting cultural drivers, such as distrust in government and social norms of impunity.

\subsection{Policy formulation}

Behavioural sciences contribute to the policy formulation phase by proposing policy solutions and by testing people's reactions ex ante. Pretesting "what works" should lead to better policies and, therefore, to the efficient allocation of public resources. Acknowledging that more information is not necessarily good for consumers (Micklitz et al., 2011), behavioural sciences have extensively tested different ways of presenting relevant information to consumers (i.e. framing of information disclosure). Examples of behaviourally informed product labelling include the energy consumption of electric appliances (London Economics and Ipsos, 2014), the environmental footprint of products (Ceci-Renaud and Tarayoun, 2016), the durability of products (SIRCOME, University of South Brittany, and University of South Bohemia, 2016) and warnings on tobacco products packages (Bogliacino et al., 2015). Likewise, behavioural sciences were used to design, test and prove the effectiveness of self-commitment devices to enhance job seekers' chances of finding employment (Behavioural Insights Team, 2012).

Here again, those applying behavioural sciences to policy may benefit from working hand in hand with social marketers. Social marketing's focus on the co-creation of policy solutions through citizens' collective intelligence (Clarke et al., 2007) would help generate innovative, citizen-led policy solutions, thereby addressing the recurring issues of low acceptance and mistrust of policies informed by behavioural sciences (Reisch and Sunstein, 2016). Moreover, social marketing can reinforce behaviourally informed policy formulations by suggesting a broader array of policy options based on disincentives and conscious decision-making (French, 2011) and by designing a fully integrated social programme rather than isolated policy solutions addressing specific causes of behaviour.

\subsection{Decision-making}

The selection of a policy solution by policy-makers is also, in essence, a behavioural issue. The ultimate decision whether to take behavioural evidence into consideration and to choose a policy option is their responsibility. Policy-makers are human and, as such, they are subject to biases, heuristics and social norms regarding, for instance, what they consider as valid evidence (Banuri et al., 2017). Behavioural sciences are beginning to contribute to the decision-making phase of policy-making. For instance, courses are being offered to policymakers (e.g. at the World Bank) to make them aware of their own decision-making biases. Behavioural sciences are likewise increasingly a part of standard curricula for master's degrees in political sciences. Perhaps this phase of the policy-making cycle is less suited for contributions of social marketing. This is a question for debate.

\subsection{Policy implementation}

Behavioural sciences can contribute to the implementation phase of policies to increase their chances of success. For this phase as well, embedding a social marketing approach in policies informed by behavioural sciences could prove worthwhile by contributing to designing pragmatic and strategic plans. Social marketing insights based, for instance, on 
segmentation using psychographic and demographic data (French and Russell-Bennett, 2015), branding (Evans, 2016), emotions (Hastings et al., 2004) and metaphoric imagery (McQuarrie and Mick, 2003) would prove particularly complementary to the way behavioural sciences are currently applied to policy. In addition, social marketers can enhance the effective implementation of behaviourally informed policies by adequately reaching their targets through appropriate media, in particular when the target consists of hard-to-reach, vulnerable individuals. Finally, behavioural sciences applied to policy could benefit from the long-term strategic approach of relationship social marketing. Rather than implementing one-off policy solutions, relationship social marketing implements dynamic, ongoing, and evolving policy solutions based on a continuous dialogue with citizens (Tapp and Spotswood, 2013). This approach would help address the recurrent issue of the longterm sustainability of interventions based on behavioural sciences' insights (Bovens, 2009).

\subsection{Policy evaluation}

Assessing the actual impact of any policy is critical to ensuring that public money is wisely spent and, where appropriate, to learn from errors. Thus far, behaviourally informed policies have too often not been properly evaluated (Lourenço et al., 2016b). One of the reasons for this lack of proper evaluation is that a robust evaluation of policies requires comparing the outcome variable between an intervention group and a control group, which is not always possible at the implementation stage. Counterfactual methods still represent an underexploited potential to assess ex post the impact of policies informed by behavioural sciences. Social marketing may successfully complement these evaluation methods, often rooted in behavioural economics, by assessing returns on investment and social impacts beyond traditional cost-benefit analysis (Puttick and Ludlow, 2012).

\section{Looking forward}

Numerous challenges, such as the depletion of natural resources, the increase of noncommunicable diseases and rising inequalities threaten societal well-being. Policies tackling these challenges will require multiple paths.

One of these paths is provided by behavioural sciences. We have outlined earlier how they inform the different stages of policy-making. Looking forward, we believe that behavioural sciences should regularly find their way into meetings and conversations at all levels in policy-making, as did cost-benefit analysis in the 1970s (Sunstein, 2012). The ideal path for behavioural sciences, therefore, is to seep into everyday political discourse and present itself as a force to counter the prevalence of economic thinking in policy.

Another path to societal well-being is social marketing. The present special issue of the Journal of Social Marketing is a testament to the discipline's ability to inform policies in order to lead to behavioural changes towards societal well-being. We have shown in this paper that social marketing is very similar to the recent trend of applying behavioural sciences to policy. In particular, both disciplines share the end-goal of contributing to greater social good, and they both build on a deep behavioural analysis based on multidisciplinary approaches focused on citizens. Despite this overall convergence, both disciplines do differ on more specific attributes such as their theoretical framework and the span of policy interventions they propose.

Because of these overwhelming similarities, these two paths converge to a large extent: social marketing can and should de facto be considered as part of the application of behavioural sciences to policy. As behavioural sciences have gained popularity in policymaking, this approach has become more inclusive over the past few years, moving away from a strictly behavioural economics framework and the corresponding nudging approach, 
JSOCM 7,4

towards the integration of other disciplines. This inclusive approach could go one step further: where appropriate, behavioural sciences applied to policy should more explicitly acknowledge and build on social marketing's insights and methods. Social marketers, in turn, can engage in a dialogue with those applying behavioural sciences to policy to explore how to pilot the convergence of both approaches in practice.

\section{2}

\section{References}

Adam, R. (2017), "The civil service fast stream in six charts", available at: www.instituteforgovernment. org.uk/blog/civil-service-fast-stream-seven-charts

Aspara, J. and Tikkanen, H. (2017), "Why do public policy-makers ignore marketing and consumer research? A case study of policy-making for alcohol advertising", Consumption Markets \& Culture, Vol. 20 No. 1, pp. 12-34, available at: https://doi.org/10.1080/ 10253866.2016.1160230

Banuri, S., Dercon, S. and Gauri, V. (2017), Biased Policy Professionals, Washington, D.C, available at: http://documents.worldbank.org/curated/en/685691498482210671/Biased-policy-professionals

Behavioural Insights Team (2011), Annual update 2010-11.

Behavioural Insights Team (2012), "New BIT trial results: helping people back into work", available at: www.behaviouralinsights.co.uk/labour-market-and-economic-growth/new-bit-trial-results-helpingpeople-back-into-work/

Behavioural Insights Team (2015), Update report 2013-2015.

Behavioural Insights Team (2016), Update Report 2015-16.

Berelson, B. (1995), "Behavioural science”, Organization Behaviour, Allied Publishers, New Delhi, p. 10.

Bogliacino, F., Codagnone, C. and Veltri, G.A. (2016), "An introduction to the special issue on the behavioural turn in public policy: new evidence from experiments”, Economia Politica, Vol. 33 No. 3, pp. 323-332, available at: https://doi.org/10.1007/s40888-016-0044-0

Bogliacino, F., Codagnone, C., Veltri, G.A., Chakravarti, A., Ortoleva, P., Gaskell, G. and Rudisill, C. (2015), "Pathos and ethos: emotions and willingness to pay for tobacco products", PLOS One, Vol. 10 No. 10, p. e0139542.

Bovens, L. (2009), "The ethics of nudge", in Grüne-Yanoff, T. and Hansson, S.O. (Eds), Preference Change, Springer, Dordrecht, pp. 207-219, available at: https://doi.org/10.1007/978-90-481-25937_10

Ceci-Renaud, N. and Tarayoun, T. (2016), Comportements d'achat en présence d'affichage environnemental: les enseignements d'une enquête par expériences de choix, Collection «Études et documents» No. 149 .

Chater, N., Huck, S. and Inderst, R. (2010), Consumer Decision-making in Retail Investment Services: A Behavioural Economics Perspective Final Report, European Commission, Brussels, p. 490.

Chetty, R., Friedman, J.N., Leth-Petersen, S., Nielsen, T.H. and Olsen, T. (2014), “Active vs. passive decisions and crowd-out in retirement savings accounts: evidence from Denmark", The Quarterly Journal of Economics, Vol. 129 No. 3, pp. 1141-1219, available at: https://doi.org/ 10.1093/qje/qju013

Cialdini, R.B. and Goldstein, N.J. (2004), "Social influence: compliance and conformity", Annual Review of Psychology, Vol. 55 No. 1, pp. 591-621, available at: https://doi.org/10.1146/annurev. psych.55.090902.142015

Clarke, J., Newman, J.E., Smith, N., Vidler, E. and Westmarland, L. (2007), Creating Citizen-Consumers: Changing Publics and Changing Public Services, SAGE Publications, London.

Codagnone, C., Bogliacino, F., Ivchenko, A., Veltri, G. and Gaskell, G. (2014), Study on Online Gambling and Adequate Measures for the Protection of Consumers of Gambling Services, European Commission, Brussels. 
Dams, V.J., Ettel, A., Greive, M. and Zschäpitz, H. (2015), "Merkel will die deutschen durch nudging erziehen”, Welt.

European Commission (2014), "Commission recommendation of 14 July 2014 on principles for the protection of consumers and players of online gambling services and for the prevention of minors from gambling online", Brussels, available at: http://eur-lex.europa.eu/legal-content/EN/ TXT/PDF/?uri=CELEX:32014H0478\&from=EN

European Commission (2015), Better Regulation “Toolbox”, European Commission, Brussels.

European Union (2014), Regulation of the European Parliament and of the Council on Key Information Documents for Packaged Retail and Insurance-based Investment Products (PRIIPs), European Union, Brussels.

Evans, W.D. (2016), Social Marketing Research for Global Public Health: Methods and Technologies, Oxford University Press, New York, NY.

French, J. (2011), "Why nudging is not enough", Journal of Social Marketing, Vol. 1 No. 2, pp. 154-162, available at: https://doi.org/10.1108/20426761111141896

French, J. and Russell-Bennett, R. (2015), "A hierarchical model of social marketing”, Journal of Social Marketing, Vol. 5 No. 2, pp. 139-159, available at: https://doi.org/10.1108/JSOCM-062014-0042

Gordon, R., Russell-Bennett, R. and Lefebvre, R.C. (2016), "Social marketing: the state of play and brokering the way forward", Journal of Marketing Management, Vol. 32 Nos 11/12, pp. 1059-1082, available at: https://doi.org/10.1080/0267257X.2016.1199156

Hallsworth, M., List, J.A., Metcalfe, R.D. and Vlaev, I. (2017), "The behavioralist as tax collector: using natural field experiments to enhance tax compliance", Journal of Public Economics, Vol. 148 (April), pp. 14-31, available at: http://dx.doi.org/10.1016/j.jpubeco.2017.02.003

Hastings, G. and Saren, M. (2003), "The critical contribution of social marketing”, Marketing Theory, Vol. 3 No. 3, pp. 305-322, available at: https://doi.org/10.1177/147059310333005

Hastings, G., Stead, M. and Webb, J. (2004), "Fear appeals in social marketing: strategic and ethical reasons for concern", Psychology and Marketing, Vol. 21 No. 11, pp. 961-986, available at: https:// doi.org/10.1002/mar.20043

International Social Marketing Association, European Social Marketing Association, and Australian Association of Social Marketing (2013), Consensus Definition of Social Marketing, ISMA, ESMA and AASM, Brisbane.

Jann, W. and Wegrich, K. (2007), "Theories of the policy cycle”, in Fischer, F., Miller, G.J. and Sidney, M.S. (Eds), Handbook of Public Policy Analysis: Theory, Politics and Methods, CRC Press, Taylor \& Francis Group, Boca Raton, FL, pp. 43-62.

Kamp, H.G.J. (2014), Kabinetsreactie op adviesrapporten van Rli, RMO en WRR over de benutting van gedragswetenschappelijke kennis in beleid, Den Haag.

Kennedy, A.M. (2015), "Macro-social marketing”, Journal of Macromarketing, Vol. 36 No. 3, pp. 354-365, available at: https://doi.org/10.1177/0276146715617509

London Economics and Ipsos (2014), Study on the Impact of the Energy Label and Potential Changes to It - on Consumer Understanding and on Purchase Decisions, London Economics and Ipsos, London.

Lotenberg, L.D. (2015), "What can social marketers learn from the accomplishments of behavioral economics? ”, Social Marketing Quarterly, Vol. 21 No. 2, pp. 59-60, available at: https://doi.org/ $10.1177 / 1524500415575230$

Lourenço, J.S., Ciriolo, E., Rafael Almeida, S. and Dessart, F.J. (2016a), Behavioural Insights Applied to Policy: Country Overviews, Luxembourg, available at: http://publications.jrc.ec.europa.eu/ repository/bitstream/JRC100547/biap\%20country\%20overviews\%202016.pdf

Lourenço, J.S., Ciriolo, E., Rafael Almeida, S. and Troussard, X. (2016b), Behavioural Insights Applied to Policy: European Report, Luxembourg, available at: https://doi.org/10.2760/903938 
JSOCM 7,4

Lunn, P. (2014), Regulatory Policy and Behavioural Economics, Paris, available at: https://doi.org/ 10.1787/9789264207851-en

McQuarrie, E. and Mick, D. (2003), "Visual and verbal rhetorical figures under directed processing versus incidental exposure to advertising”, Journal of Consumer Research, Vol. 29 No. 4, pp. 579-587, available at: https://doi.org/10.1086/346252

Madrian, B.C. (2014), “Applying insights from behavioral economics to policy design”, Annual Review of Economics, Vol. 6 No. 1, pp. 663-688, available at: https://doi.org/10.1146/annurev-economics080213-041033

Madrian, B.C. and Shea, D.F. (2001), "The power of suggestion: inertia in 401(k) participation and savings behavior*", The Quarterly Journal of Economics, Vol. 116 No. 4, pp. 1149-1187.

Marchiori, D.R., Adriaanse, M.A. and De Ridder, D.T.D. (2017), "Unresolved questions in nudging research: putting the psychology back in nudging", Social and Personality Psychology Compass, Vol. 11 No. 1, p. e12297, available at: https://doi.org/10.1111/spc3.12297

Micklitz, H.W., Reisch, L.A. and Hagen, K. (2011), "An introduction to the special issue on behavioural economics, consumer policy, and consumer law”, Journal of Consumer Policy, Vol. 34 No. 3, pp. 271-276, available at: https://doi.org/10.1007/s10603-011-9166-5

Obama, B. (2015), Executive Order - Using Behavioral Science Insights to Better Serve the American People, Washington, DC.

OECD (2017), Behavioural Insights and Public Policy, Lessons from around the World, OECD Publishing, Paris, available at: https://doi.org/http://dx.doi.org/10.1787/9789264270480-en

Oullier, O. (2013), "Behavioural insights are vital to policy-making”, Nature, Vol. 501 No. 7468, p. 463, available at: https://doi.org/10.1038/501463a

Peattie, S. and Peattie, K. (2003), "Ready to fly solo? Reducing social marketing's dependence on commercial marketing theory", Marketing Theory, Vol. 3 No. 3, pp. 365-385, available at: https:// doi.org/10.1177/147059310333006

Puttick, R. and Ludlow, J. (2012), Standards of Evidence for Impact Investing, Nesta, London.

Reisch, L.A. and Sunstein, C.R. (2016), "Do Europeans like nudges?”, Judgment and Decision Making, Vol. 11 No. 4, pp. 310-325, available at: journal.sjdm.org/16/16202b/jdm16202b.pdf

Russell-Bennett, R. (2016), "Social marketing”, in Baker, M. and Hart, S. (Eds), The Marketing Book, Routledge, London.

Russell-Bennett, R., Wood, M. and Previte, J. (2013), "Fresh ideas: services thinking for social marketing", Journal of Social Marketing, Vol. 3 No. 3, pp. 223-238, available at: https://doi.org/ 10.1108/JSOCM-02-2013-0017

Schuster, L. (2015), "Competition and its influence on consumer decision making in social marketing", Journal of Marketing Management, Vol. 31 Nos 11/12, pp. 1333-1352, available at: https://doi.org/ 10.1080/0267257X.2015.1015598

Shafir, E. (2013a), "Introduction", in Shafir, E. (Ed.), The Behavioral Foundations of Public Policy, Princeton University Press, Princeton, NJ, pp. 1-9.

Shafir, E. (2013b), The Behavioral Foundations of Public Policy, Princeton University Press, Princeton, NJ.

SIRCOME, University of South Brittany, and University of South Bohemia (2016), The Influence of Lifespan Labelling on Consumers, Brussels.

Sunstein, C.R. (2012), "The stunning triumph of cost-benefit analysis”, Bloomberg View.

Sunstein, C.R. (2014), "Nudging: a very short guide”, Journal of Consumer Policy, Vol. 37 No. 4, pp. 583-588, available at: https://doi.org/10.1007/s10603-014-9273-1

Tapp, A. and Spotswood, F. (2013), "From the 4Ps to COM-SM: reconfiguring the social marketing mix", Journal of Social Marketing, Vol. 3 No. 3, pp. 206-222, available at: https://doi.org/10.1108/ JSOCM-01-2013-0011 
Thaler, R.H. and Sunstein, C.R. (2008), Nudge: Improving Decisions about Health, Wealth and Happiness, Yale University Press, New Haven, CT and London.

van Bavel, R., Herrmann, B., Proestakis, A. and Esposito, G. (2013), Applying Behavioural Sciences to EU Policy-making, JRC Scientific and Policy Reports, available at: https://doi.org/10.2788/4659

World Bank Group (2015), World Development Report 2015: Mind, Society, and Behaviour, available at: https://doi.org/10.1596/978-1-4648-0342-0

Corresponding author

François J. Dessart can be contacted at: francois.dessart@ec.europa.eu

For instructions on how to order reprints of this article, please visit our website: www.emeraldgrouppublishing.com/licensing/reprints.htm Or contact us for further details: permissions@emeraldinsight.com 